\title{
Sediment quality assessment of the tributaries of the Santos-São Vicente Estuarine System - Brazil
}

\author{
Perina, F.C. ${ }^{1}$; Torres, R. J. ${ }^{2}$; Mozeto, A.A. ${ }^{3}$; Nascimento, M.R.L. ${ }^{4}$ \& Abessa, D.M.S. ${ }^{1}$ \\ 1. UNESP, Instituto de Biociências - Campus do Litoral Paulista, Universidade Estadual Paulista "Júlio de Mesquita Filho", \\ São Vicente, São Paulo, Brazil \\ 2. UNIFESP, Instituto do Mar - Campus Baixada Santista, Universidade Federal de São Paulo, Santos, São Paulo, Brazil \\ 3. UFSCAR, Departamento de Química, Universidade Federal de São Carlos, São Carlo, São Paulo, Brazil \\ 4. Conselho Nacional de Energia Nuclear, Poços de Caldas, MG, Brazil.
}

Received January 10, 2018; Accept April 27, 2018

\begin{abstract}
The Santos-São Vicente Estuarine System has a long history of environmental impacts, and several studies have been performed in this region. However, the quality of its tributaries was not previously studied. This study aimed to investigate the quality of sediments from five rivers (Santana, Mariana, Piaçabuçu, Quilombo, and Diana Rivers) and three sampling sites at Piaçaguera Canal (riverbed, right and left banks), by using an integrated approach involving chemical analyses and whole sediment toxicity tests. Chronic and acute toxicity tests were performed using, respectively, copepods Nitocra sp. and amphipods Tiburonella viscana. The studied sediments presented moderate to high levels of PAHs, PCBs, metals ( $\mathrm{Cu}, \mathrm{Hg}, \mathrm{Ni}, \mathrm{Pb}, \mathrm{Zn})$, and As. The majority of sediments produced chronic toxic effects, and samples from Piaçaguera Canal were consistently toxic in all acute and chronic tests. The integration of data through multivariate analyses indicated that the toxicity was closely related to the sediments contamination. Chemical data were compared with sediment quality guidelines, which evidenced that the sitespecific values are adequate to predict impacts. The levels of organic chemicals and metals suggest constant inputs from diffuse and point sources, demanding actions to ensure effective control and management of the contamination sources to the estuary.
\end{abstract}

Key words: Contamination; toxicity; amphipod; copepod; metal, PAH, PCB, multivariate analysis.

\section{INTRODUCTION}

Throughout history, humans have used the water bodies for receiving and diluting wastes. Coastal regions and estuaries in particular tend to experience intense human occupation, which puts high pressure on the marine and estuarine ecosystems. In Brazil, for example, 14 of the country's 25 metropolitan regions are located in estuarine regions, as are the country's main petroleum production facilities and port systems (Lamparelli et al., 2001). As consequence, these ecosystems are exposed to intense and varied anthropic impacts, which lead to a loss of natural resources and biodiversity, and negative effects to the biota (Long et al., 1995).

The deposition of materials such as suspended sediments, organic material, and man-made contaminants is more *Corresponding author: Fernando Cesar Perina; e-mail: perinafc@gmail.com extensive in estuaries, because these environments exhibit geomorphological and physical-chemical characteristics that favor such deposition (Du Laing et al., 2009). The aspects that control the mobility of these contaminants include changes in salinity, temperature, $\mathrm{pH}$, and oxidation/reduction potential, all of which regulate the retention and release of chemicals associated with the finest sediment fraction, organic material, iron oxides, and sulfides (Rae, 1997). The contaminants may be shifted around different compartments of the sediment matrix, which includes interstitial water, the solid phase (sediment, suspended particles, organic matter, and biota), and the sediment-water interface (Jickells \& Rae, 1997). Therefore, sediments can be considered one of the most complex matrices in the aquatic ecosystems, which are important indicators of environmental quality (Power \& Chapman, 1992). 
Chemical analyses may provide information on the nature and specific levels of contaminants, which, if bioavailable, may lead to toxicity and bioaccumulation. However, different types of associations between contaminants and sediments may reduce their bioavailability to the biota (Araújo et al., 2006). For this reason, a sediment contamination assessment performed exclusively through chemical analyses is often insufficient for estimating damages to aquatic organisms. When this approach is performed alone, it only detects the nature of contamination and quantifies the concentrations present in the environment; it does not provide information on the contaminants bioavailability or their possible effects on the biota. Thus, toxicity tests give a biological significance to the chemical data and complement the studies of environmental contamination.

Toxicity tests are standardized methods used to assess deleterious effects on living organisms exposed to a substance, mixture of substances or environmental sample. These procedures are performed under controlled conditions, where previously selected organisms are exposed for a period of time to the sample of interest, and then the response is evaluated. Therefore, toxicity tests are extremely important for evaluating sediment quality, because they provide information on the effects caused by complex mixtures.
One of the most important Brazilian industrial complexes is located in the vicinity of the Santos-São Vicente Estuarine System (SSES), where the biggest port of South America is installed. Several studies performed in this area have evaluated sediment quality though chemical analyses and toxicity tests (Abessa et al., 1998; 2008; 2014a; Lamparelli et al., 2001; Cesar et al., 2006; Choueri et al., 2009; Torres et al., 2009; 2014; Buruaem et al., 2013). Although some of these studies have assessed the sediment quality at the inner parts of the estuary, information on the sediments of the SSES tributaries was not properly investigated. Therefore, in order to evaluate the extent of contamination and toxicity of the SSES, the objective of this study was to assess the quality of the sediments of the SSES tributaries, using an integrated approach that combines sediment chemistry and toxicity tests.

\section{MATERIALS AND METHODS}

\section{Sediment sampling}

Two sampling campaigns were performed (summer and winter 2006) in which the sampling stations were distributed in

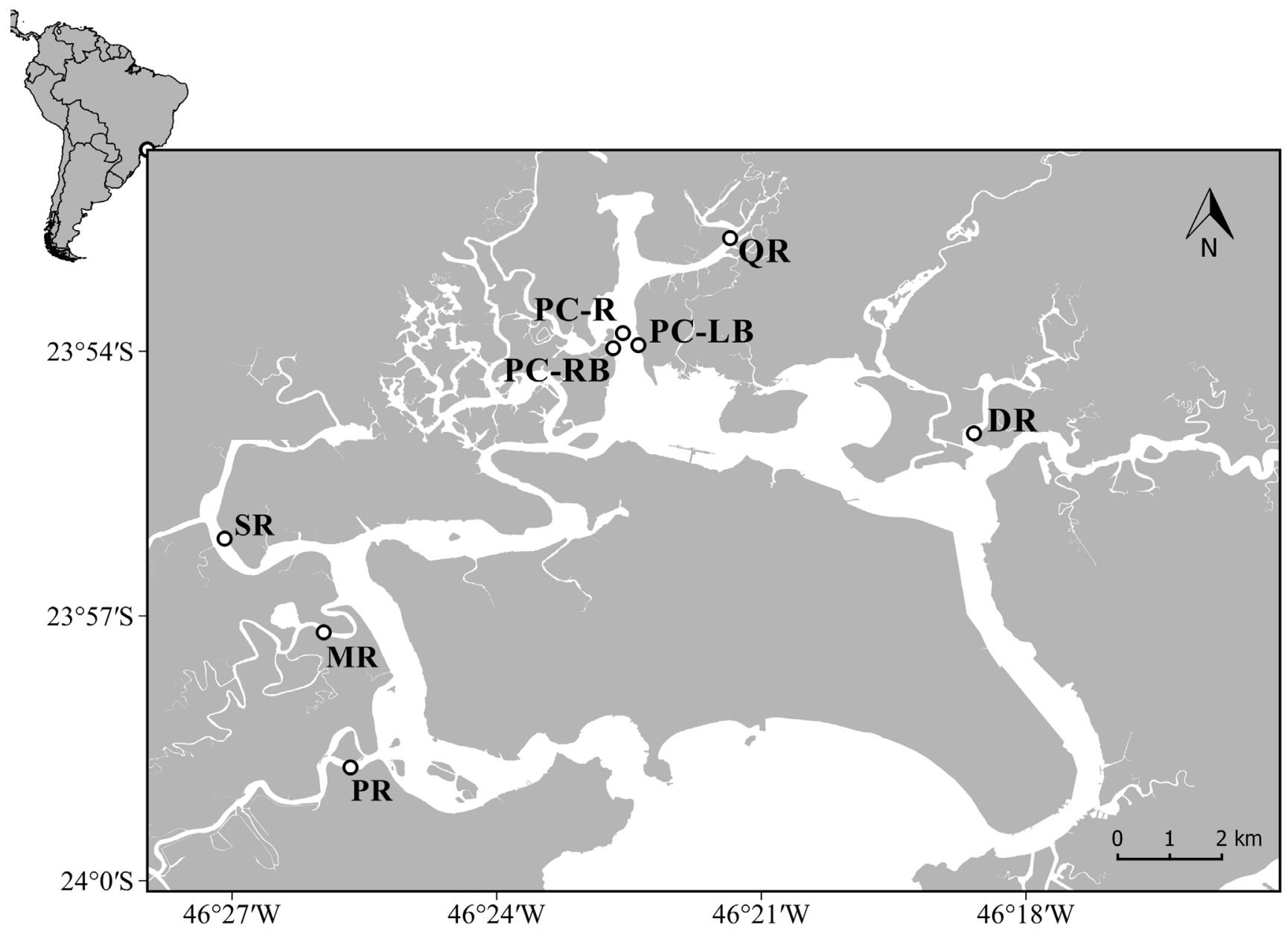

Figure 1. Geographic locations of the sediment collection sites in the Santos-São Vicente Estuarine System tributaries: Piaçabuçu River (PR), Mariana River (MR), Santana River (SR), Quilombo River (QR), Diana River (DR), Piaçaguera Canal riverbed (PC-R), Piaçaguera Canal right bank (PC-RB) and Piaçaguera Canal left bank (PC-LB). 
eight different sites within the SSES (Figure 1). Five sampling sites were situated at the rivers Piaçabuçu (PR), Mariana (MR), Santana (SR), Quilombo (QR), and Diana (DR); and other three sampling sites were set up in the Piaçaguera Canal at riverbed (PC-R), right bank (PC-RB) and left bank (PCLB). Surface sediments were collected with a Van-Veen grab, and kept on ice in thermal boxes. In the laboratory, the aliquots for the ecotoxicological assays were stored at $4^{\circ} \mathrm{C}$, while those for the geochemical analyses were stored at $-20^{\circ} \mathrm{C}$. Aliquots of sediment samples for the sediment texture analyses were separated and left to dry at $60^{\circ} \mathrm{C}$ for three days before use.

\section{Sediment properties and chemical analyses}

Sediment grain size distribution was analyzed based on the protocol proposed by Mudroch \& Macknight (1994). This technique consists of wet sieving $100 \mathrm{~g}$ of previously dried sediments through a $0.062-\mathrm{mm}$ mesh to separate sandy fractions; followed by settling time determination (to measure silts and clays) with a calibrated hydrometer. Subsequently, the sandy material retained on the $0.062-\mathrm{mm}$ mesh was sieved into different meshes ( $\phi$ scale) in order to separate different classes of sands. The classification method was based on the scale established by Wentworth (1992).

Total organic carbon was determined by combustion at $900^{\circ} \mathrm{C}$ for total carbon and phosphoric acid addition for inorganic carbon, which are transformed into $\mathrm{CO}_{2}$. Calcium carbonate was determined according to the protocol described by Hirota \& Szyper (1976). This technique consists of separating fractions of $5 \mathrm{~g}$ of each sediment sample and then adding $10 \mathrm{ml}$ of hydrochloric acid $(5 \mathrm{~N} \mathrm{HCl})$ for $24 \mathrm{~h}$ to eliminate calcium carbonates. Afterward, samples were washed with distilled water and dried at $60^{\circ} \mathrm{C}$. The difference between initial and final weights showed the amount of $\mathrm{CaCO}_{3}$ in the samples.

The elements $\mathrm{Ag}, \mathrm{As}, \mathrm{Cd}, \mathrm{Cu}, \mathrm{Cr}, \mathrm{Hg}, \mathrm{Ni}, \mathrm{Pb}, \mathrm{Se}$ and $\mathrm{Zn}$ were extracted from sediments according to USEPA Method 3050B (USEPA, 1996a). Concentrations of $\mathrm{Cu}, \mathrm{Cr}$, $\mathrm{Ni}, \mathrm{Pb}$, and $\mathrm{Zn}$ were determined by flame atomic absorption spectrophotometry (F-AAS). In regard to $\mathrm{Ag}$ and $\mathrm{Cd}$ the determinations were performed by graphite furnace (GF$\mathrm{AAS})$. For As and Se the concentration was determined by hydrate generation (HG-AAS). Mercury ( $\mathrm{Hg}$ ) was extracted by combining USEPA Methods 245.5 and 245.6 (USEPA, 1991). Hg concentrations were determined by cold vapor spectrophotometry (CV-AAS).

Polycyclic aromatic hydrocarbons (PAH) and polychlorinated biphenyls (PCB) were extracted from sediments according to USEPA Method 3550B (USEPA, 1996b), and then passed through a clean-up column with silica gel following the USEPA Method 3630C (USEPA, 1996c). Extracts were analyzed by gas chromatography mass spectrometer (GC-MS) with methods prepared for each class of compounds that were evaluated. PAH were analyzed according to Method 8270C (USEPA, 1996d). The method to quantify PCB was adapted from USEPA Methods 8081B, 8082A, and 8275A (USEPA, 1996e; 1998; 2000; respectively). Detailed descriptions of the chemical analyses of PAHs and PCBs, as well as the respective Quality Assurance / Quality Control (QC/QA) procedures, are available in Torres et al. (2009).

\section{Whole sediment toxicity tests}

In order to assess whole sediment toxicity, two approaches were carried out: the chronic toxicity test using the benthic copepod Nitocra sp. and the acute toxicity test with the burrowing amphipod Tiburonella viscana. Physical and chemical parameters $(\mathrm{pH}$, salinity, dissolved oxygen, and temperature) were checked at the beginning and end of each experiment. The reference sediment and dilution water were collected at Engenho d'Água Beach, in the city of Ilhabela, SP, Brazil. This location was chosen due to lack of reference site for the SSES, since the sediments are influenced by anthropogenic activities to varying degrees. Moreover, Engenho D'água Beach presents low levels of contamination (Abessa et al., 2008) and has been used as a reference site by several environmental studies (Cesar et al., 2006; Buruaem et al., 2013; Abessa et al., 2014a).

The chronic toxicity assay with the copepod Nitocra sp. was performed with whole-sediment following the protocol developed by Lotufo \& Abessa (2002). Sediments were introduced into high-density $10-\mathrm{mL}$ polyethylene test chambers, forming a layer of approximately $0.5 \mathrm{~cm} ; 8 \mathrm{~mL}$ of filtered sea water were then added to each test chamber. Four replicates per sample were used; each one received 5 ovigerous females of Nitocra sp. The test system was kept at $25 \pm 2{ }^{\circ} \mathrm{C}$ and under a photoperiod of $16: 8$ light:dark for 10 days. At the end of the experiment, the contents of each test chamber were fixed through the addition of $1 \mathrm{~mL}$ formaldehyde $(4 \%)$ and Rose-Bengal dye $(0.1 \%)$. The sublethal effects on reproduction were estimated by counting the total number of offspring (nauplii and copepodites) divided by the number of surviving females.

The acute toxicity assay with whole-sediment followed the protocol described by Melo \& Abessa (2002), using the amphipod Tiburonella viscana. Organisms were collected from Engenho d'Água Beach (Ilhabela, SP) by using a manual dredge. The animals were transported to a laboratory and acclimated for 3 days in tanks containing filtered seawater and reference sediment, at $25 \pm 2^{\circ} \mathrm{C}$, and under constant lighting and aeration. Tests were conducted in high density polyethylene flasks with $1 \mathrm{~L}$ holding capacity. Prior to the test, the sediment samples were thoroughly homogenized, and then a layer of approximately $2 \mathrm{~cm}$ (about $175 \mathrm{~mL}$ ) of sediment was placed in each test chamber together with about $750 \mathrm{~mL}$ of filtered seawater. After 24 hours, ten adult and non ovigerous organisms were introduced into each test-chamber. The testing system was kept under constant lightning, aeration and temperature $\left(25 \pm 2^{\circ} \mathrm{C}\right)$. Four replicates of each sample and control were prepared (sediment from Ilhabela, origin of the amphipods). The number of dead organisms was counted daily. After 10 days, the experiments were concluded and the sediment was sieved $(0.5 \mathrm{~mm}$ net); the number of survivors was counted in each replicate. 


\section{Statistical analyses}

The toxicity tests data were checked by normality and homoscedasticity by Shapiro-Wilks and Bartlett's tests, respectively. Then, the results were compared with their respective controls using the Student's t'-test. Sediments were considered toxic when identified significant differences between the references and the test-samples to each toxicity endpoint. Sediments were classified as toxic, nontoxic, or exhibiting a sign of toxicity (when no significant effect was observed, but exhibit more than $30 \%$ difference between the tested sample and the reference sample).

The data were integrated using exploratory techniques. In order to determine the direct association between the variables, a multiple correlation analysis was carried out, using Pearson's product with significance level of $95 \%$. The second approach aimed to understand the indirect associations; to achieve that, the data were integrated through multivariate analysis (Factor Analysis, with the extraction by Principal Component Analysis). Two separate PCAs were conducted on the biological and chemical results, one for summer, and the other one for winter. In the interpretation of PCA data, the eigenvalues higher than 1.0 were considered (Kaiser's criteria). A component loading cutoff of 0.40 was used in selecting variables for inclusion into factors (Tabachnick \& Fidell, 1996). Finally, to classify the samples, we used a cluster analysis (Bray Curtis distance; Group Average Link), as proposed by Cesar et al. (2009).

\section{RESULTS AND DISCUSSION}

\section{Sediment characteristics}

Results obtained for sediment properties and chemical analyses are summarized in the Table 1. In summer, sediment samples from the rivers Piaçabuçu, Quilombo, Diana and Piaçaguera Canal (banks) were predominantly sandy (fines percentages ranging between 17 and 29\%); whereas sediments from the rivers Mariana and Santana were muddy $(88 \%$ and $54 \%$ of mud particles, respectively). However, all sediment samples were muddy in winter, excepting the samples from Mariana and Diana rivers, where fine sand was predominant (61\% and $77 \%$, respectively).

The highest total organic carbon (TOC) quantities were found in the sediment samples from PC-LB and Quilombo River (8.6\% and $8.0 \%$, respectively), collected in the summer campaign. Generally, sandy sediments present low amounts of TOC in relation to muddy sediments (Du Laing et al., 2009). However, these samples had small amounts of fine sediments (about 24\% for both PC-LB and Quilombo River) in comparison to the other samples. Possibly this aspect may be related to the lower influence of tidal currents in these sites. In winter, the sediment sample from the Santana River showed the highest TOC quantity (6.2\%). The sediment from Santana River presented a higher content of $\mathrm{CaCO}_{3}(11.6 \%)$, while the other samples presented levels ranging from $3.47 \%$ to $8.7 \%$.

\section{Comparison with sediment quality guidelines}

In Brazil there are no standards for contaminants concentrations in sediments. However, there is a law for dredged sediments established by CONAMA Resolution 454/2012 (Brasil, 2012). This resolution proposes the use of some sediment quality guidelines (SQGs) and establishes that the characterization of sediments prior to dredging should be based on an evaluation of physical, chemical, and ecotoxicological parameters. The SQGs adopted in this resolution consist of a combination of various international sediment quality guidelines, particularly those established by the Canadian Council of Minister of the Environment (CCME, 2002), and the North American Effects Range, which set forth for marine and estuarine environments (Long et al., 1995). Therefore, the results of chemical analyses were compared with the Interim Sediment Quality guidelines (ISQG $=$ TEL - threshold effect Level) and Probable Effect Levels - PEL (CCME, 2002), as well as with the Effects Range Low (ERL) and Effects Range Median (ERM) (Long et al., 1995) in order to provide interpretation in global perspective. Moreover, to provide interpretation of chemical data in a local perspective the results were compared with threshold and probable effects from site-specific sediment quality values (SQVs) derived for the Santos Estuarine System (Choueri et al., 2009), based on sediment physical-chemical, toxicological, and benthic community data integrated through multivariate analysis. The SQVs proposed by Choueri et al. (2009) yield two thresholds, termed "SQG-low" and "SQG-high". Chemical concentrations lower than SQG-low were considered not harmful to aquatic biota. On the other hand, concentrations of contaminants above SQG-high are potentially harmful to the ecosystem.

The total PAHs in the sediment from PC-RB $(6841 \mu \mathrm{g} \mathrm{Kg}$ $\left.{ }^{1}\right)$ exceeded the level 1 of the CONAMA Resolution 454/12 (4000 $\mu \mathrm{g} \mathrm{Kg}^{-1}$, which corresponds to the North American ERL). Also, this value exceeded the site-specific SQG-high (1660 $\mu \mathrm{g} \mathrm{Kg}^{-1}$ ) (Choueri et al., 2009), thus the sediment of this site is considered as polluted by these contaminants. In this sampling station, 10 of $15 \mathrm{PAHs}$ compound exceeded the TEL. According to standards stated by CONAMA 454/2012, the compounds Benz[a]anthracene, Benzo[a] pyren, Chrysene, Anthracene, Fluoranthene and Pyrene exceeded their corresponding threshold levels (Level 1) which are 280, 230, 85.3, 600 and $665 \mu \mathrm{g} \mathrm{Kg}^{-1}$, respectively. Moreover, the compounds Fluoranthene and Pyrene exceeded their corresponding PEL values (1494 and $1398 \mu \mathrm{g} \mathrm{Kg}^{-1}$, respectively). These compounds also violated the TEL in sediments from PC-R, which are $113 \mu \mathrm{g} \mathrm{Kg}^{-1}$ to Fluoranthene and $153 \mu \mathrm{g} \mathrm{Kg}^{-1}$ to Pyrene. Acenaphthene and Acenaphthylene exceeded the corresponding TEL values (6.71 and 5.87, respectively) in the sediments from PC-R and Diana River.

Concerning total PCBs, metals and As, the Figure 2 presents the contaminants concentrations in the tributaries and their respective SQGs adopted in this study. PCBs concentrations were below TEL $\left(21.5 \mathrm{mg} \mathrm{Kg}^{-1}\right)$. In regard of the site-specific SQG, sediment samples from the Piaçabuçu River and 
Table 1. Sediment properties and chemical analyses of samples from SSES tributaries.

\begin{tabular}{|c|c|c|c|c|c|c|c|c|}
\hline \multicolumn{9}{|c|}{ SUMMER } \\
\hline Characteristics (\%) & PR & MR & SR & PC-RB & PC-R & PC-LB & QR & DR \\
\hline Medium sand & 6.2 & 2.9 & 16.4 & 21.6 & 31.4 & 17.9 & 33.4 & 11.3 \\
\hline Fine sand & 76.5 & 9.1 & 30.1 & 49.0 & 28.2 & 57.8 & 42.3 & 72.2 \\
\hline Silt & 9.2 & 58.0 & 34.2 & 24.1 & 25.7 & 14.8 & 10.1 & 8.7 \\
\hline Clay & 8.1 & 30.0 & 19.3 & 5.3 & 14.7 & 9.5 & 14.2 & 7.8 \\
\hline TOC & 3.2 & 3.3 & 7.9 & 1.2 & 2.7 & 8.6 & 8.0 & 0.9 \\
\hline $\mathrm{CaCO}_{3}$ & $\mathrm{NP}$ & NP & $\mathrm{NP}$ & NP & NP & $\mathrm{NP}$ & $\mathrm{NP}$ & NP \\
\hline \multicolumn{9}{|c|}{ Metal and semi-metal $\left(\mathrm{mg} \mathrm{Kg}^{-1}\right)$} \\
\hline As & 7.4 & 6.4 & 7.3 & 7.6 & 8.0 & 8.9 & 9.2 & 2.5 \\
\hline $\mathrm{Cd}$ & $<\mathrm{QL}$ & $<\mathrm{QL}$ & 0.1 & 0.1 & 0.1 & $<\mathrm{QL}$ & 0.3 & $<\mathrm{QL}$ \\
\hline $\mathrm{Cr}$ & 28.9 & 19.1 & 34.9 & 45.1 & 41.7 & 29.8 & 53.0 & 9.0 \\
\hline $\mathrm{Cu}$ & 8.9 & 2.9 & 16.1 & 22.8 & 25.8 & 14.0 & 28.7 & 1.1 \\
\hline $\mathrm{Hg}$ & 0.2 & 0.6 & 0.2 & 1.2 & 0.7 & 1.2 & 0.3 & 0.2 \\
\hline $\mathrm{Ni}$ & 10.1 & 8.0 & 17.3 & 23.1 & 20.0 & 14.3 & 26.7 & 3.8 \\
\hline $\mathrm{Pb}$ & 23.0 & $<\mathrm{QL}$ & 27.0 & 31.5 & 28.0 & 20.3 & 63.0 & $<\mathrm{QL}$ \\
\hline $\mathrm{Zn}$ & 57.5 & 27.3 & 93.0 & 110.0 & 118.8 & 61.0 & 189.5 & 18.7 \\
\hline \multicolumn{9}{|c|}{ WINTER } \\
\hline Characteristics (\%) & PR & MR & SR & PC-RB & PC-R & PC-LB & QR & DR \\
\hline Medium sand & 2.4 & 1.7 & 7.3 & 2.7 & 2.8 & 6.6 & 6.6 & 0.2 \\
\hline Fine sand & 44.3 & 60.6 & 13.6 & 27.2 & 38.6 & 35.9 & 18.2 & 77.4 \\
\hline Silt & 21.8 & 14.3 & 40.7 & 52.6 & 33.6 & 32.0 & 41.6 & 12.9 \\
\hline Clay & 31.5 & 23.3 & 38.4 & 17.6 & 25.0 & 25.5 & 33.6 & 9.5 \\
\hline TOC & 2.4 & 3.3 & 6.2 & 4.1 & 5.4 & 3.0 & 2.9 & 0.8 \\
\hline $\mathrm{CaCO}_{3}$ & 6.8 & 5.7 & 11.6 & 7.9 & 8.8 & 8.7 & 4.5 & 3.4 \\
\hline \multicolumn{9}{|c|}{ Organic compounds $\left(\mu \mathrm{g} \mathrm{Kg}^{-1}\right)$} \\
\hline Benz[a]anthracene & 4.9 & 2.6 & 2.8 & 505.6 & 50.6 & 16.0 & 30.5 & 9.5 \\
\hline Benzo[a]pyrene & 5.7 & 1.5 & 2.3 & 475.7 & 60.7 & 18.9 & 36.1 & 9.0 \\
\hline Chrysene & 6.5 & 1.0 & 1.7 & 551.3 & 61.1 & 16.5 & 21.4 & 8.3 \\
\hline Dibenz[a,h]anthracene & ND & 1.0 & ND & 22.9 & 3.9 & 1.4 & 1.9 & 2.6 \\
\hline Acenaphthene & 1.3 & 1.2 & 0.7 & 12.5 & 7.2 & 5.1 & 1.5 & 11.4 \\
\hline Acenaphthylene & 1.8 & 1.4 & 1.0 & 29.6 & 7.1 & 1.6 & 4.2 & 10.7 \\
\hline Anthracene & 3.4 & 1.3 & 1.5 & 104.5 & 18.7 & 3.3 & 5.4 & 21.4 \\
\hline Phenanthrene & 4.4 & 2.3 & 2.2 & 106.4 & 28.4 & 4.6 & 7.2 & 22.9 \\
\hline Fluoranthene & 11.5 & 5.0 & 5.0 & 2264.9 & 123.3 & 34.0 & 32.7 & 21.7 \\
\hline Fluorene & ND & ND & ND & 13.8 & 8.4 & ND & 3.6 & 14.5 \\
\hline Naphthalene & ND & ND & 1.2 & 7.0 & 13.1 & 0.9 & 2.7 & 5.5 \\
\hline Pyrene & 10.5 & 5.0 & 6.6 & 2166.2 & 195.2 & 49.1 & 125.5 & 23.3 \\
\hline Benzo[b]fluoranthene & 4.5 & 1.9 & 2.0 & 431.6 & 56.7 & 18.7 & 32.5 & 12.3 \\
\hline Indeno[1,2,3-cd]pyrene & 1.3 & 0.9 & ND & 81.9 & 12.7 & 4.4 & 7.8 & 3.4 \\
\hline Benzo[ghi]perylene & 1.0 & ND & 0.6 & 67.3 & 11.4 & 3.8 & 6.8 & 2.3 \\
\hline$\Sigma \mathrm{PAH}$ & 56.7 & 25.0 & 27.6 & 6841.0 & 658.4 & 178.4 & 319.9 & 178.8 \\
\hline$\Sigma$ PCB & 1.0 & 0.3 & 0.0 & 1.3 & 2.1 & 1.1 & 0.0 & 0.0 \\
\hline \multicolumn{9}{|c|}{ Metal and semi-metal (mg Kg $\left.\mathbf{~}^{-1}\right)$} \\
\hline As & 2.5 & 10.9 & 8.9 & 4.3 & 6.5 & 3.7 & 3.3 & 1.5 \\
\hline $\mathrm{Cd}$ & $<\mathrm{QL}$ & $<\mathrm{QL}$ & $<\mathrm{QL}$ & 0.1 & 0.1 & $<\mathrm{QL}$ & $<\mathrm{QL}$ & $<\mathrm{QL}$ \\
\hline $\mathrm{Cr}$ & 7.1 & 33.1 & 20.1 & 25.4 & 34.6 & 16.6 & 19.1 & 9.4 \\
\hline $\mathrm{Cu}$ & $<\mathrm{QL}$ & 5.9 & 4.4 & 8.4 & 18.6 & 3.1 & 4.1 & $<\mathrm{QL}$ \\
\hline $\mathrm{Hg}$ & 0.3 & 0.6 & 0.3 & 0.4 & 0.4 & 0.4 & 0.7 & 0.2 \\
\hline $\mathrm{Ni}$ & $<\mathrm{QL}$ & 11.4 & 8.8 & 11.0 & 17.1 & 7.7 & 7.3 & $<\mathrm{QL}$ \\
\hline $\mathrm{Pb}$ & $<\mathrm{QL}$ & 17.5 & $<\mathrm{QL}$ & 15.3 & 31.8 & 0.0 & 0.0 & 38.3 \\
\hline $\mathrm{Zn}$ & 7.9 & 52.0 & 40.6 & 53.0 & 98.0 & 28.6 & 41.7 & 11.7 \\
\hline
\end{tabular}

PR: Piaçabuçu River, MR: Mariana, SR: Santana River, QR: Quilombo River, DR: Diana River, PC-R: Piaçaguera Canal riverbed, PC-RB Piaçaguera Canal right bank and PC-LB: Piaçaguera Canal left bank.

$\mathrm{NP}=$ not performed.

$\mathrm{ND}=$ not detected.

$\mathrm{QL}=$ quantification limit (Cd: $0.02 \mathrm{mg} \mathrm{kg}^{-1}$; Ni: $\left.2.5 \mathrm{mg} \mathrm{kg}^{-1} ; \mathrm{Pb}: 5.0 \mathrm{mg} \mathrm{kg}^{-1}\right)$. 
Piaçaguera Canal (riverbed and banks) exceeded SQG-low $\left(0.94 \mu \mathrm{g} \mathrm{Kg}^{-1}\right)$, but did not violate SQG-high $\left(2.61 \mu \mathrm{g} \mathrm{Kg}^{-1}\right)$. According to Choueri et al. (2009), biological responses are not predictable in the concentration range in between these two thresholds, and then the sediments containing PCBs into this interval are considered as moderately polluted.

The São Paulo's State Environmental Regulatory Agency (CETESB) presented an inventory of contamination sources to the SSES, indicating several major industries, point and diffuse sewage inputs, and landfills (Lamparelli et al., 2001). According to these authors, the sources of PAHs to the estuary may be the substances used or produced by the industrial processes, together with port activities, combustion of coal and petroleum fuels and landfills; whereas the PCBs concentrations in SSES suggest a diffuse contribution of these pollutants (atmospheric deposition of PCBs released by factories.

The chemical analyzes revealed that all sediments from the SSES tributaries presented metals contamination at any degree. In summer, concentrations above the TEL were found for $\mathrm{Cr}$ (Quilombo River); $\mathrm{Cu}$ (PC-RB, PC-R and Quilombo River); $\mathrm{Pb}$ (PC-RB, and Quilombo River), Zn (Quilombo River). Regarding the site-specific SQGs, sediment samples did not exceed the thresholds for $\mathrm{Cd}, \mathrm{Cr}$ and $\mathrm{Cu}$. On the other hand, concentration above SQG-low was observed for $\mathrm{Ni}$ in all sediment samples, except for the Diana River. Concentrations above the SQG-low also were found for $\mathrm{Zn}$ at PC-LB and Quilombo River. Sediments from Piaçaguera Canal (riverbed and banks), and Piaçabuçu, Santana and Quilombo Rivers presented $\mathrm{Pb}$ exceeding the SQG-high established for SSES.

In the winter campaign, concentrations of $\mathrm{Pb}$ in the sediments from PC-R and Diana River exceeded the TEL and the SQG-high. Moreover, this metal was above the SQG-low in the sediments from PC-RB and Mariana River. In PC-R sediment was also found $\mathrm{Zn}$ above the SQG-low value. Most of sediment samples, with exception of those from Piaçabuçu and Diana Rivers, presented Ni concentration above SQGlow value.

Considering the two sampling campaigns, sediments collected near the industrial complex presented higher concentration of $\mathrm{Cr}$. From this region towards the bay of Santos, there is an apparent decrease in the concentration of this metal. Overall, the sampling sites present $\mathrm{Cu}$ levels below the SQGs, with the exception of the Quilombo River and two sites from Piaçaguera Canal, where a previous study reported concentrations of $\mathrm{Cu}$ at $164.0 \mathrm{mg} \mathrm{Kg}^{-1}$ (Luiz-Silva \& Machado, 2012) and $157.7 \mathrm{mg} \mathrm{Kg}^{-1}$ (Cesar et al., 2006), respectively. According to CETESB, the sources of $\mathrm{Cu}$ can be industrial effluents and some port terminals of liquid bulk. Regarding Ni, among the inputs of this metal to the estuary there are the point sources (industrial effluents) and diffuse sources (port terminals and atmospheric pollution). The $\mathrm{Pb}$ levels measured in this study are related to industrial sources, with the highest contamination observed in the sampling sites closer to a large steel plant and to the industrial complex of
Cubatão. Furthermore, there is a port terminal of a chemistry factory near the Diana River, which could be a possible source of $\mathrm{Pb}$. Although the other rivers have shown $\mathrm{Pb}$ levels below the TEL, these values are above the site-specific SQG-high, which are evidence of diffuse sources of this metal. The sediments of the studied SSES tributaries were also somewhat contaminated with $\mathrm{Zn}$, especially the sites near industrial sources. According to the State Environmental Regulatory Agency (Lamparelli et al., 2001), the main source of $\mathrm{Zn}$ in the estuary is the steel industry.

The $\mathrm{Hg}$ was the main contaminant found in the sediments of SSES tributaries. $\mathrm{Hg}$ concentrations in all sediments exceeded the TEL and the site-specific SQGlow in both summer and winter campaigns. The highest $\mathrm{Hg}$ concentrations were observed in the sediments from PC-RB and PC-LB, exceeding the PEL in summer. Furthermore, the SQG-high was exceeded at Piaçaguera Canal (riverbed and banks), Mariana and Quilombo rivers in both seasons. Since $\mathrm{Hg}$ sources are not known for the Piaçabuçu, Mariana and Santana Rivers (Lamparelli et al., 2001), the presence of this metal seems to depend not only on point sources (industrial complex and some port terminals), but also on diffuse sources. Indeed, Hortellani et al. $(2005 ; 2008)$ and Abessa et al. (2008) suggested that the broad spatial distribution of $\mathrm{Hg}$ across the SSES may be due to multiple sources, such as the industrial effluents, landfills and atmospheric deposition.

Concerning the metalloid As, the sediment collected in the Quilombo River presented higher concentration in summer (9.2 $\mathrm{mg} \mathrm{Kg}^{-1}$ ), which corroborate with literature, since LuizSilva et al. (2006) reported levels of As ranged from 5 to 13 $\mathrm{mg} \mathrm{Kg}{ }^{-1}$ in the Morrão River (a tributary of the Quilombo River). Moreover, only the sediments from the Mariana and Diana rivers did not exceed the Canadian TEL in the summer campaign. However, in winter, the sediments of Mariana and Santana Rivers presented As concentrations above the TEL. But when it is compared with the site-specific SQVs, As did not exceed threshold levels. According to CETESB, there are no specific industrial sources of As in the SSES, thus its presence may be due to diffuse sources, such as raw materials or wastes (Lamparelli et al., 2001). Potential sources of this element in the region are domestic and industrial dumping sites located on the banks of the Cubatão River and Piaçabuçu River. These landfills, scattered around the estuary, consist of legal and illegal industrial and domestic wastes disposal sites and were installed along the mid and late $20^{\text {th }}$ century. They still represent a considerable source of contamination to the internal areas of the estuarine system (Fortunato et al., 2012; Schepis et al., 2016).

Metals in estuaries may be originated from natural sources involving both local geological composition and the leaching of soils and rocks present in the drainage basin. Nevertheless, the greatest contribution comes from human sources, such as domestic and industrial effluents (Du Laing et al., 2009), which is strongly influenced by rainfall intensity (Pereira et al., 2006). The results indicated that in general the sediments from the SSES tributaries exhibited higher concentrations of metals 

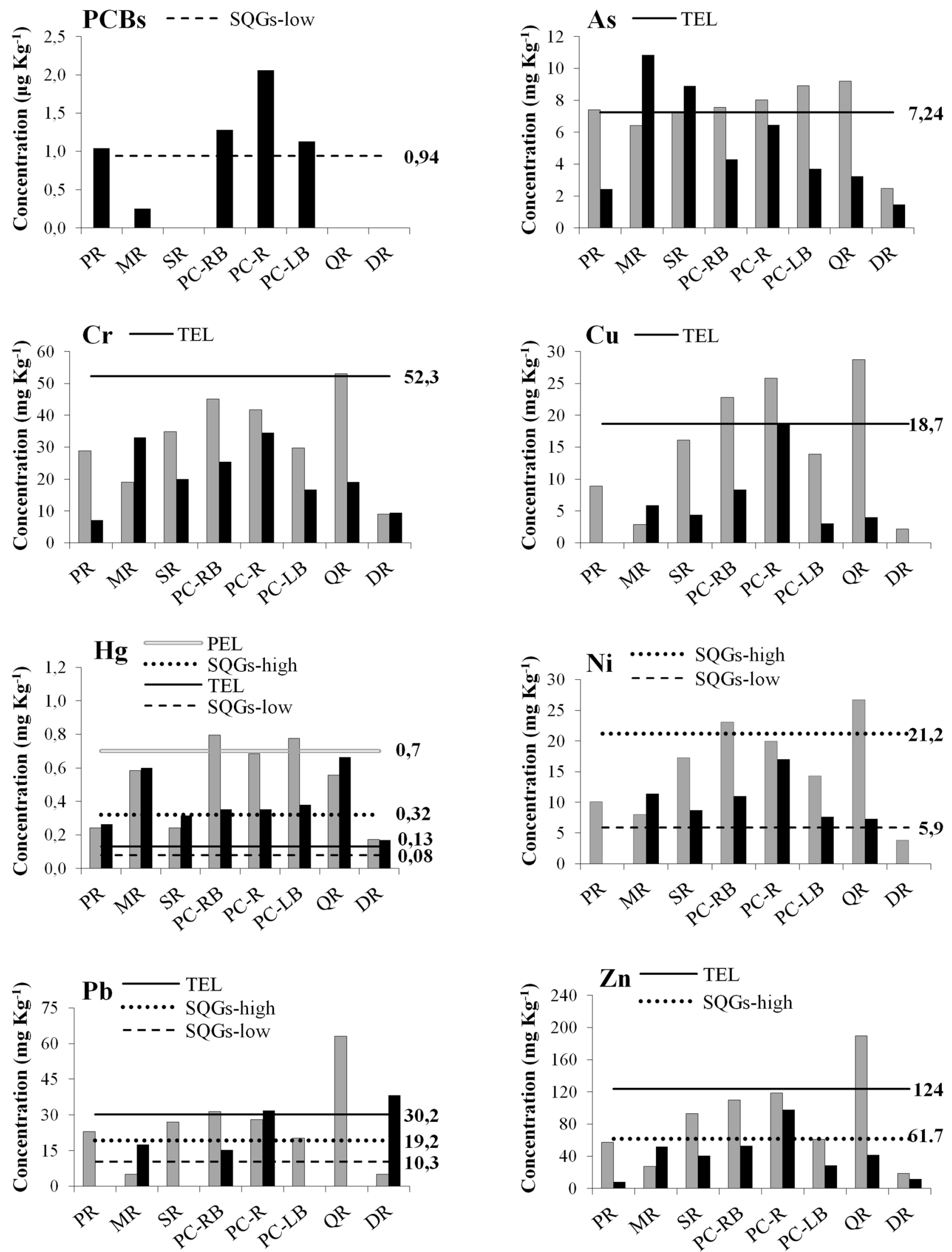

Figure 2. Concentrations of total PCBs, arsenic and metals in sediments from SSES tributaries, collected in summer (grey bars) and winter (black bars); and their respective sediment quality guidelines values adopted in this study: TEL and PEL (CCME, 2002); SQG-low and SQG-high (Choueri et al., 2009). PR: Piaçabuçu River, MR: Mariana, SR: Santana River, QR: Quilombo River, DR: Diana River, PC-R: Piaçaguera Canal riverbed, PC-RB Piaçaguera Canal right bank and PC-LB: Piaçaguera Canal left bank. 
during the summer, which is the rainier season; this pattern was more evident in the Quilombo River. Similar results were also observed by Luiz-Silva et al. (2006), who investigate the spatial and seasonal variability of metals in the northern portion of SSES. In the summer campaign the precipitation rate accumulated in the 15 days prior to sampling was 226.5 $\mathrm{mm}$, whereas in the winter campaign it was $87.7 \mathrm{~mm}$. In fact, studies have shown that concentrations of metals increase in river sediments during the rainy season (Cunha et al., 2007; Abessa et al., 2014b). Abessa et al. (2014b) detected eventual differences in the geochemistry of sediments after periods of moderate and extreme rainfalls. Additionally, Cunha et al. (2007) stated that extreme rainfalls were related to an increase in the adsorption and complexation reactions between fines, organic matter, metals and nutrients.

The rainwater runoff may drag a series of contaminants deposited on soils or associate to sediment particles, as pesticides and metals, among others (Bay et al., 1996). The contaminants tend to be carried to low energy areas, as estuaries, where contaminated particles set, producing environmental contamination (Carr et al., 2000). As a matter of fact, there is a decrease in the concentration of metals from the northern portion of SSES towards the bay of Santos, mainly in the summer (rainy season). This gradient of contamination from the inner to the outer portions of the SSES was previously reported (Lamparelli et al., 2001; Abessa et al., 2008; Torres et al., 2009). According to Hortellani et al. (2005), besides the presence of metal sources, the inner portions of the SSES are also affected by tides restricting water circulation, which hinders the dispersion of the contaminants and their accumulation in the sediments.

\section{Whole sediment toxicity tests}

The physical and chemical parameters of the overlying water in the test-chambers during the bioassay with $T$. viscana were considered appropriate (Melo \& Abessa, 2002). Temperatures ranged between 24.3 and $25.4^{\circ} \mathrm{C}$; dissolved oxygen ranged from 6.2 to $9.8 \mathrm{mg} \mathrm{L}^{-1}$; $\mathrm{pH}$ levels were between 7.6 and 8.8; and salinities ranged from 34 to 35 .

In the summer campaign, the amphipods exposed to sediments from Piaçaguera Canal (both banks and riverbed) and Quilombo River exhibited significant mortalities (Figure 3a). Moreover, sediments from the rivers Mariana and Santana showed a sign of toxicity. In winter, the mortalities of amphipod were significant in the sediments from the three sampling stations in the Piaçaguera Canal (riverbed and banks), and Mariana River (Figure 3a). In this season, signs of toxicity were observed in the sediments from Piaçabuçu, Santana and Quilombo rivers.

In the chronic toxicity test, the measured parameters of overlying waters were within acceptable levels (Lotufo \& Abessa, 2002). Dissolved oxygen levels ranged from 4.1 to 5.4 $\mathrm{mg} \mathrm{L}^{-1} ; \mathrm{pH}$ ranged between 7.20 and 8.26; and salinities ranged from 17 to 20 . In the summer campaign, only the copepods exposed to sediment from Diana River did not produced fecundity rates significantly lower than those animals exposed to the reference sediment. On the other hand, fecundity rates of copepods exposed to sediments collected in winter were significant lower in all stations samples; thus, these sediments were considered toxic to Nitocra sp. (Figure 3b).

When the results of both seasons are compared, it is possible to notice that all sediment samples presented toxicity in at least one assay (table 2). Based on the results, it is evident that the sediments from the Piaçaguera Canal (PCRB, PC-R and PC-LB) presented poor quality, and all samples collected in that area produced adverse effects. Sediments from Quilombo and Mariana rivers presented acute toxicity in summer and winter, respectively. Diana River sediments caused adverse effects only in the chronic toxicity assay in winter; moreover, sediment from this site showed no sign of acute toxicity in both seasons.

The bioavailability of the contaminants in the studied sediments was evidenced by the ecotoxicological tests. The sediments with the highest levels of As in summer (Quilombo River) and winter (Mariana River) showed acute toxicity to amphipods. The sediments from Diana River did not show chronic toxicity in summer, but when this site presented the highest level of $\mathrm{Pb}$, fecundity rates were significantly different from the reference sediment.

In order to verify connections among variables, correlation analyses were performed using the Pearson linear correlation coefficients $(p<0.05)$. In summer, acute toxicity presented strong correlations with $\mathrm{Hg}$ (coefficient calculated at 0.88); and moderate correlation with As and $\mathrm{Ni}$ (0.58 and 0.50, respectively). The chronic toxicity correlated positively high with As (coefficient calculated at 0.79); and presented moderate correlation with $\mathrm{Cr}$ and $\mathrm{Ni}$ ( 0.59 and 0.51 , respectively). These results suggested that probably these contaminants influenced directly the sediment toxicity. In fact, $\mathrm{Hg}$ concentrations exceeded the site-specific SQG-high in sediments from Piaçaguera Canal, Quilombo and Mariana rivers, and the same samples presented acute toxicity. Although the survival rates of amphipods exposed to sediment from Mariana River were statistically similar to those observed in the reference sediment, the mean of amphipod survival was less than $40 \%$. Moreover, with the exception of Diana River sediment, all samples presented chronic toxicity in summer and these sediments exceeded the site-specific SQG-low for $\mathrm{Ni}$. In addition, excepting the sample from Mariana River, all the sediments presented concentrations of As exceeding the TEL.

The table 3 presents correlation analyses made to verify connections among the variables in the winter. Amphipod survival presented a negative correlation with $\mathrm{Ni}$, PAHs and PCBs; whereas copepod fecundity was negatively correlated with $\mathrm{Cr}, \mathrm{Cu}, \mathrm{Ni}$ and $\mathrm{Zn}$. Mud presents very strong correlation with As, strong correlation with $\mathrm{Cr}$, and moderate correlation with Ni. Moderate to strong correlation was observed between TOC content and $\mathrm{As}, \mathrm{Cr}, \mathrm{Cu}, \mathrm{Ni}$ and $\mathrm{Zn}$ concentrations (correlation coefficient of around 0.7). 


\section{Multivariate Analysis Approach}

The use of factor analysis provided a deeper insight into data, and revealed associations of chemical concentrations in sediment and the biological effects. PCA results are presented in Tables 4 and 5. In summer, three factors explained $88.4 \%$ of the total variance (table 4). The first factor (PC1) explained $53.3 \%$ of the variances; it showed positive correlations to the concentrations of $\mathrm{As}, \mathrm{Cd}, \mathrm{Cu}, \mathrm{Ni}, \mathrm{Pb}, \mathrm{Zn}$ and TOC; these variables were negatively correlated with the amphipod survival and copepod fecundity (indicators of absence of toxicity). This factor represented the association of organic carbon, metals and biological responses. Apart from $\mathrm{Cd}$, all these metals presented high concentrations, at potentially toxic levels to the test-organisms. The second factor (PC2), accounted for $22.4 \%$ of the variances and combined mud and concentration of $\mathrm{Hg}$, which were inversely correlated with amphipod survival and copepod fecundity. This factor suggested that the biological effects could be related to the concentrations of $\mathrm{Hg}$. As previously presented, $\mathrm{Hg}$ concentrations are above the SQGs. The third factor (PC3) accounted for the $12.7 \%$ variances and again associated $\mathrm{Hg}$ and mud, but with positive loadings, which were negatively correlated with amphipod survival. Such correlation suggests that this contaminant was strongly associated with the fine particles and was an important contributor to the acute toxicity. This metal was found in levels above the site-specific SQG-high in the sediments that presented acute toxicity to amphipods (all the sampling sites situated at Piaçaguera Canal and Quilombo River).

In winter, three factors explained $85.9 \%$ of the total variances (table 5). The first factor (PC1) accounted for 49.6\% of variances. Positive loadings were evidenced to PCBs, all the PAH compounds, $\mathrm{Cu}, \mathrm{Ni}$, and $\mathrm{Zn}$, and silt contents; amphipod survival and copepod fecundity were negatively correlated with this factor. These results suggested that probably these contaminants were associated to fines particles and influenced (a)

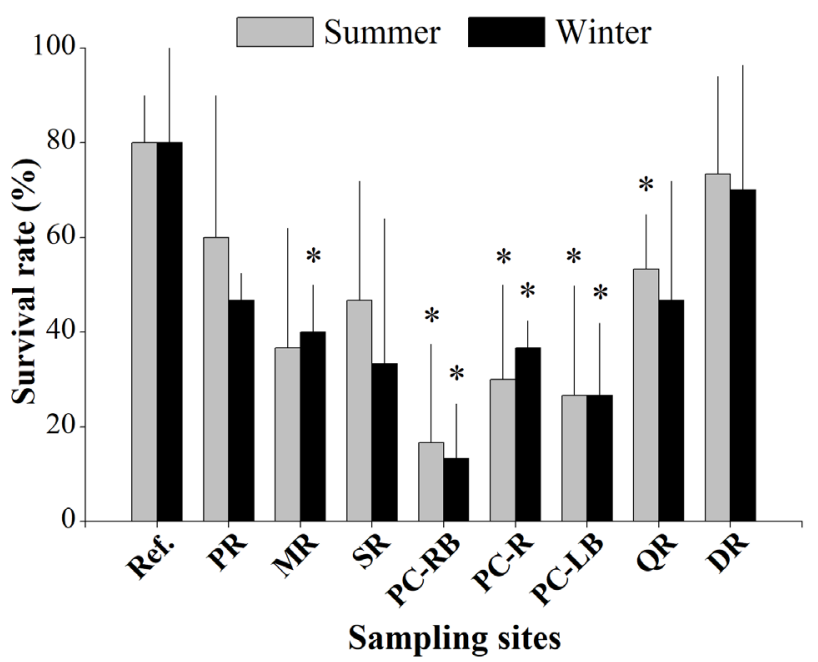

(b) Chronic toxicity - Nitocra sp.

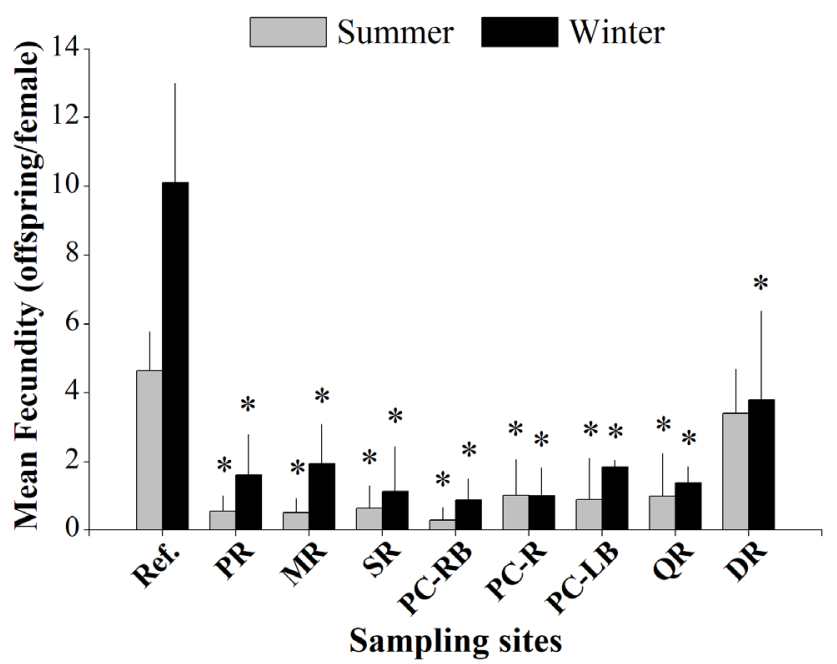

Figure 3. Whole sediment toxicity: (a) Mean survival rates of the amphipod Tiburonella viscana and (b) Mean fecundity rates of Nitocra sp. exposed to sediments from the SSES tributaries. Asterisks $(*)$ indicate significant differences relative to the reference $(\mathrm{p}<0.05)$. Results are presented as means \pm standard deviations (error bars).

Table 2. Comparative results obtained in sediment toxicity tests for samples collected in SSES tributaries.

\begin{tabular}{|c|c|c|c|c|}
\hline \multirow{2}{*}{ Sampling sites } & \multicolumn{2}{|c|}{ Acute toxicity } & \multicolumn{2}{|c|}{ Chronic toxicity } \\
\hline & Summer & Winter & Summer & Winter \\
\hline PR & not toxic & sign of toxicity & toxic & toxic \\
\hline MR & sign of toxicity & toxic & toxic & toxic \\
\hline SR & sign of toxicity & sign of toxicity & toxic & toxic \\
\hline PC-RB & toxic & toxic & toxic & toxic \\
\hline PC-R & toxic & toxic & toxic & toxic \\
\hline PC-LB & toxic & toxic & toxic & toxic \\
\hline QR & toxic & sign of toxicity & toxic & toxic \\
\hline DR & not toxic & not toxic & not toxic & toxic \\
\hline
\end{tabular}

PR: Piaçabuçu River, MR: Mariana, SR: Santana River, QR: Quilombo River, DR: Diana River, PC-R: Piaçaguera Canal riverbed, PC-RB Piaçaguera Canal right bank and PC-LB: Piaçaguera Canal left bank. 
directly the sediment toxicity. The second factor (PC2) explained $23.5 \%$ of variances. In this factor, both indicators of absence of toxicity were inversely correlated with all metals, excepting the $\mathrm{Pb}$, which were associated with clay, $\mathrm{CaCO}_{3}$, and TOC in the sediment. Hence, this factor tended to associate contaminants with geochemical carriers (clay, TOC and $\mathrm{CaCO}_{3}$ ) and toxicity to organisms tested. This factor showed negative correlation for sand, since these particles are reported to be almost nonreactive compared to fine particles (Sageman \& Lyons, 2003). The Factor 3 explained 12.8\% of variances, showing positive correlations for $\mathrm{Cr}, \mathrm{Cu}, \mathrm{Pb}$, $\mathrm{Zn}$, some PAH compounds (Fluorene and Naphthalene), and negative correlations to fines.

In order to separate the SSES tributaries with different degrees of sediments quality, according to geochemical and ecotoxicological properties, cluster analysis were conducted with each data set (Figures 4 and 5, to summer and winter, respectively), as proposed by Cesar et al. (2009). In summer, due to the absence of data (such as $\mathrm{CaCO}_{3}$, PAHs and PCBs), the cluster analysis was unclear concerning degradation degrees and relationship among the sites. However, Diana River was placed isolated from the others sites; this sediment showed absence of toxicity and the lowest levels of metals, although it presented moderate levels of $\mathrm{Hg}$; hence this site could be classified as low or not degraded. In the sequence appears the Mariana River, which could be classified as low degraded. Then, there is a larger group, subdivided according to the degree of degradation; where Piaçabuçu River was associated with PC-LB; in the sequence was linked two different groups. The first one contemplates the Santana and Quilombo Rivers. Finally, the last group, containing PC-R and PC-RB, which could be classified as degraded sites.

In winter, Diana River also was placed isolated from the others sampling sites; although its sediments presented $\mathrm{Pb}$ above the SQG-high, moderate contamination by some PAHs, and chronic toxicity. Therefore, this site could be classified as low to moderately degraded. A second group was formed by the rivers Mariana and Santana, which showed evidence of acute toxicity, contamination by $\mathrm{As}, \mathrm{Hg}$ and $\mathrm{Ni}$ (concentrations above TEL and site-specific SQG) and could be classified as moderately degraded. Piaçabuçu River (chronic toxicity, signal of acute toxicity, contamination by $\mathrm{Hg}$ and PCBs) could be classified as moderately degraded as well. The Quilombo River and the PC-LB showed more evidences of degradation (Hg concentration exceeding SQG-high, Ni values above SQGlow) and could be classified as degraded. In this analysis, PC-R and PC-RB were again placed isolated from the other sampling stations; besides in this season the percentage of similarity with the other samples was lower; probably it is due to concentrations of PCBs, the high levels of PAHs and the stronger toxicity to amphipods. Therefore, PC-R and PC-RB could be classified as highly degraded. In the winter, the clusters formed seemed to be indicating not only the different degrees of contamination among sites, but also the influence of different pollution sources in each estuarine region. These aspects are further discussed in the next section of this paper.

\section{Sediment quality of the Santos-São Vicente Estuarine System tributaries}

Overall, sediment from Diana River was classified as low to moderately degraded. The chronic toxicity of these sediments in the winter campaign may be related to the port operations. Acenaphthene, Acenaphthylene, and $\mathrm{Pb}$ (the highest value of this metal in winter) were found in these sediments. Despite the absence of acute toxicity observed, previous studies reported high mortality of amphipods exposed to sediments from Diana Island (collected near our

Table 3. Correlation analysis of sediment properties, chemical contaminants and toxicity tests results of samples from SSES tributaries. Variables significantly correlated and their respective Pearson linear correlation coefficients $(\mathrm{p}=0.05)$ are highlighted.

\begin{tabular}{|c|c|c|c|c|c|c|c|c|c|c|c|c|c|c|}
\hline & $\begin{array}{c}\text { Amphipod } \\
\text { survival }\end{array}$ & $\begin{array}{l}\text { Copepod } \\
\text { fecundity }\end{array}$ & Mud & $\mathrm{CaCO}_{3}$ & TOC & $\Sigma \mathrm{PCB}$ & $\Sigma \mathrm{PAH}$ & $\mathrm{Zn}$ & $\mathrm{Pb}$ & $\mathrm{Ni}$ & $\mathrm{Hg}$ & $\mathrm{Cu}$ & $\mathrm{Cr}$ & $\mathrm{Cd}$ \\
\hline As & -0.34 & -0.38 & 0.96 & 0.45 & 0.65 & -0.09 & -0.12 & 0.52 & -0.04 & 0.64 & 0.41 & 0.40 & 0.74 & $0.10-$ \\
\hline $\mathrm{Cr}$ & -0.48 & -0.50 & 0.71 & 0.27 & 0.61 & 0.36 & 0.23 & 0.91 & 0.28 & 0.95 & 0.49 & 0.84 & - & \\
\hline $\mathrm{Cu}$ & -0.42 & -0.56 & 0.29 & 0.37 & 0.65 & 0.68 & 0.26 & 0.98 & 0.39 & 0.91 & 0.16 & - & & \\
\hline $\mathrm{Hg}$ & -0.20 & -0.36 & 0.47 & -0.20 & 0.11 & -0.22 & -0.08 & 0.32 & -0.35 & 0.42 & - & & & \\
\hline $\mathrm{Pb}$ & 0.40 & 0.49 & 0.05 & -0.37 & -0.21 & 0.18 & 0.10 & 0.32 & - & & & & & \\
\hline $\mathrm{Zn}$ & -0.44 & -0.58 & 0.43 & 0.35 & 0.69 & 0.54 & 0.23 & - & & & & & & \\
\hline$\Sigma \mathrm{PAH}$ & -0.63 & -0.38 & -0.14 & 0.11 & 0.16 & 0.35 & - & & & & & & & \\
\hline$\Sigma \mathrm{PCB}$ & -0.50 & -0.46 & -0.18 & 0.37 & 0.31 & - & & & & & & & & \\
\hline TOC & -0.64 & -0.79 & 0.44 & 0.86 & - & & & & & & & & & \\
\hline Survival & - & & & & & & & & & & & & & \\
\hline
\end{tabular}

Values marked in bold are negatively correlated with amphipod survival and copepod fecundity. 
Table 4. Principal component analysis (PCA) based on chemical contamination and effects on amphipod survival and copepod fecundity exposed to sediments of Santos-São Vicente Estuarine collected in the summer.

\begin{tabular}{lccc}
\hline & PC & & \\
\hline Variables & 1 & 2 & 3 \\
$\mathrm{As}$ & $\mathbf{0 . 8 6}$ & -0.30 & 0.01 \\
$\mathrm{Cd}$ & $\mathbf{0 . 8 0}$ & 0.35 & -0.37 \\
$\mathrm{Cr}$ & $\mathbf{0 . 9 9}$ & 0.02 & 0.02 \\
$\mathrm{Cu}$ & $\mathbf{0 . 9 5}$ & 0.11 & 0.09 \\
$\mathrm{Hg}$ & 0.32 & $\mathbf{- 0 . 5 2}$ & $\mathbf{0 . 7 3}$ \\
$\mathrm{Ni}$ & $\mathbf{0 . 9 8}$ & 0.01 & 0.03 \\
$\mathrm{~Pb}$ & $\mathbf{0 . 9 3}$ & 0.32 & -0.12 \\
$\mathrm{Zn}$ & $\mathbf{0 . 9 5}$ & 0.23 & -0.14 \\
& & & \\
TOC & $\mathbf{0 . 5 0}$ & -0.03 & -0.38 \\
Sand & 0.15 & $\mathbf{0 . 8 0}$ & $\mathbf{0 . 5 4}$ \\
Mud & -0.15 & $\mathbf{- 0 . 8 0}$ & $\mathbf{- 0 . 5 4}$ \\
& & & \\
Amphipod survival & -0.48 & 0.74 & -0.44 \\
Copepod Fecundity & $\mathbf{- 0 . 5 8}$ & $\mathbf{0 . 6 5}$ & 0.05 \\
Eigenvalue & & & \\
Total of variance (\%) & 6.93 & 2.91 & 1.65 \\
Cumulative (\%) & 53.3 & 22.4 & 12.7 \\
\hline Bold indicates sign & 53.3 & 75.7 & 88.4 \\
\hline
\end{tabular}

Bold indicates significant correlation.

sampling site) (Cesar et al., 2006; Buruaem et al., 2013). It should be noted that dredging activities in the Santos harbour may be a sporadic source of toxicity and contamination to Diana River. The dredging along the navigation channel promotes an overflow plume composed by a mixture of fine particles and the contaminants associated, that may reach the surrounding areas, including this sampling site.

The sites located in the eastern portion of the SSES (Piaçabuçu, Mariana and Santana Rivers) were classified as moderately degraded. The toxicity of the sediments collected in these sites are probably related to diffuse sources of contamination (i.e., domestic sewage, urban drainage and waste disposal landfills), which may be contributing to inputs of $\mathrm{PCBs}, \mathrm{As}, \mathrm{Hg}, \mathrm{Ni}$ and $\mathrm{Pb}$, together with other not measured contaminants. Sewage may receive contribution from rain water and urban drainage waters containing high concentrations of PCBs, metals, as well as ammonia and detergents, which increasing their toxic potential (Bay et al., 1996; Abessa et al., 2014a). Although the latter has been considered a confounding factor in ecotoxicological studies (Ankley et al., 1992; Ward et al., 2011), since it can occur naturally, ammonia can also interact with other contaminants and have additive or synergistic effects that considerably increase toxicity (Ankley et al., 1990). It was shown that in the presence of ammonia, sediments presenting moderate levels of contamination become toxic (Araújo et al., 2013; Camargo et $a l ., 2015)$. Therefore, even when contamination levels are low to moderate, due to the presence of ammonia and detergents, they are still harmful to biota in many instances (Phillips et al., 1997; Abessa et al., 2014a). However, ammonia levels
Table 5 Principal component analysis (PCA) based on chemical contamination and effects on amphipod survival and copepod fecundity exposed to sediments of Santos-São Vicente Estuarine collected in the winter.

\begin{tabular}{lccc}
\hline & PC & & \\
\hline Variables & 1 & 2 & 3 \\
$\mathrm{As}$ & -0.09 & $\mathbf{- 0 . 7 8}$ & 0.18 \\
$\mathrm{Cr}$ & 0.36 & $\mathbf{- 0 . 7 2}$ & 0.49 \\
$\mathrm{Cu}$ & 0.46 & -0.61 & 0.59 \\
$\mathrm{Hg}$ & -0.10 & $\mathbf{- 0 . 5 0}$ & -0.11 \\
$\mathrm{Ni}$ & $\mathbf{0 . 4 2}$ & $\mathbf{- 0 . 7 9}$ & 0.40 \\
$\mathrm{~Pb}$ & 0.24 & 0.35 & $\mathbf{0 . 8 9}$ \\
$\mathrm{Zn}$ & 0.41 & -0.70 & 0.55
\end{tabular}

\begin{tabular}{|c|c|c|c|}
\hline Benz[a]anthracene & 0.97 & 0.07 & -0.20 \\
\hline Benzo[a]pyrene & 0.98 & 0.06 & -0.18 \\
\hline Chrysene & 0.97 & 0.07 & -0.18 \\
\hline Dibenz[a,h]anthracene & 0.98 & 0.11 & -0.10 \\
\hline Acenaphthene & 0.71 & 0.54 & 0.36 \\
\hline Acenaphthylene & 0.94 & 0.31 & 0.01 \\
\hline Anthracene & 0.97 & 0.20 & -0.07 \\
\hline Phenanthrene & 0.98 & 0.17 & -0.01 \\
\hline Fluoranthene & 0.96 & 0.09 & -0.21 \\
\hline Fluorene & 0.66 & 0.55 & 0.44 \\
\hline Naphthalene & 0.56 & -0.05 & 0.68 \\
\hline Pyrene & 0.97 & 0.07 & -0.20 \\
\hline Benzo[b]fluoranthene & 0.98 & 0.07 & -0.18 \\
\hline Indeno[1,2,3-cd]pyrene & 0.98 & 0.07 & -0.16 \\
\hline Benzo[ghi]perylene & 0.98 & 0.06 & -0.16 \\
\hline PCBs & 0.48 & -0.26 & 0.27 \\
\hline TOC & 0.26 & -0.86 & -0.01 \\
\hline $\mathrm{CaCO}_{3}$ & 0.17 & -0.68 & -0.23 \\
\hline Sand & 0.13 & 0.64 & -0.25 \\
\hline Silt & 0.66 & -0.39 & -0.42 \\
\hline Clay & -0.39 & -0.67 & -0.52 \\
\hline Amphipod survival & -0.63 & 0.59 & 0.37 \\
\hline Copepod Fecundity & -0.41 & 0.79 & 0.33 \\
\hline Eigenvalue & 14.9 & 7.0 & 3.8 \\
\hline Total of variance (\%) & 49.6 & 23.5 & 12.8 \\
\hline Cumulative (\%) & 49.6 & 73.1 & 85.9 \\
\hline
\end{tabular}

Bold indicates significant correlation.

were not measured in the present study, which could explain some correlations between the low levels of some metals and the biological effects.

The Piaçabuçu River receives domestic sewage in natura and the river basin drains areas affected by former industrial landfills, which are contaminated by a variety of chemicals (Cesar et al., 2006). Furthermore, there was a dumping ground (deactivated in 2003) close to the right bank of this river. The Mariana River receives treated domestic sewage, but the most 


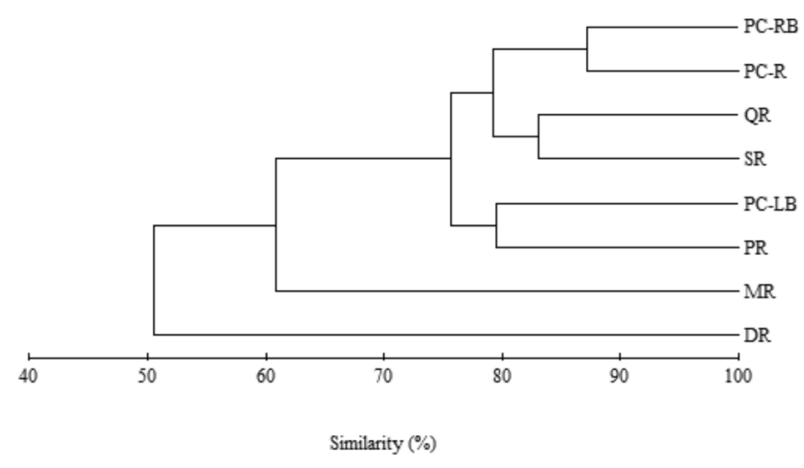

Figure 4. Cluster analyses showing the groups of Santos-São Vicente Estuarine System tributaries according to the quality of sediment in the summer.

important source of contamination to this site seems to be an illegal industrial landfill located close to this site (deactivated in 1993). The main contamination source to the Santana River possibly is a factory which processes metallurgical wastes (slag). In addition, the Branco River, a tributary of the Santana River, also presents an illegal industrial landfill (deactivated in 1993).

The most degraded sediments ware collected in the northern portion of the SSES (PC-RB, PC-R, PC-LB and Quilombo River). According to Lamparelli et al. (2001), this part of the estuary is affected by the Cubatão River, which receives most of the effluents from the Cubatão industrial complex (including a petroleum refinery plant and several fertilizer and chemical plants); this area is under influence of a major steel plant (considered the main source of PAHs and some metals to the SSES, according to CETESB) and a fertilizer plant. These results suggest that such levels were due to industrial discharges, since this sampling site is situated in the vicinity of privative terminals of fertilizers and a major steel industry, which are potentially polluting agents. As reported by Luiz-Silva \& Machado (2012), anomalous concentration of iron (i. e. above local background) in sediments from Morrão River (tributary of the Quilombo River) was attributed to the inflow from the steel plant; accordingly, contents also anomalous of $\mathrm{Cr}, \mathrm{Pb}$, and $\mathrm{Zn}$ showed positive correlations with those of Fe and were interpreted as an indication of a common source for these metals.

Sediments from Piaçaguera Canal (PC-RB, PC-R and PC$\mathrm{LB})$ showed the highest values of $\mathrm{PCB}, \mathrm{Cr}, \mathrm{Cu}, \mathrm{Ni}$ and $\mathrm{Zn}$ in the winter. Moreover, this region presented the highest levels $\mathrm{Hg}$ and PAHs, corroborating the results obtained by other studies carried out at Piaçaguera Canal (Abessa et al., 2008; Cesar et al., 2006; Torres et al., 2015; Buruaem et al., 2013). The Piaçaguera Canal was created from the dredging and rectification of the Mogi and Piaçaguera Rivers, in order to enable the installation of port terminals. Since the project was concluded in 1965, it requires periodic dredging to maintain adequate depths for ship navigation. For the disposal of the dredged sediments, a dam was built at right bank of the canal, occupying more than 1.5 million square meters, this dam receives not only dredged material but mainly the residues from the steel plant (Lamparelli et al., 2001). Indeed, the sediments of the PC-R (navigation channel of this industry) presented some PAH compounds above the TEL values, but

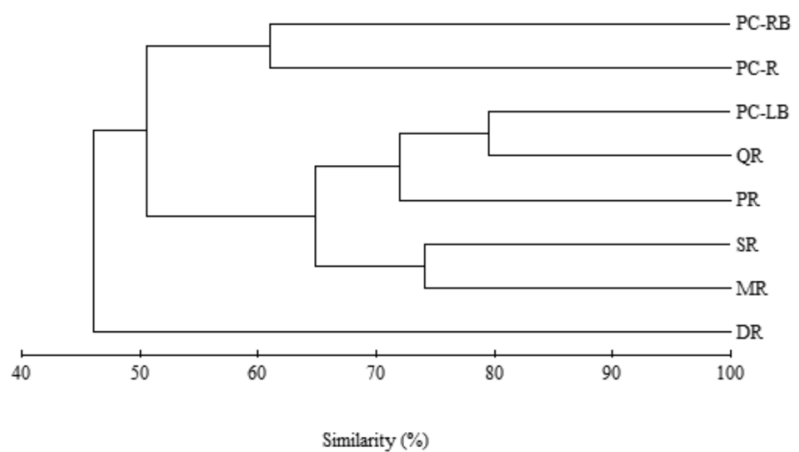

Figure 5. Cluster analyses showing the groups of Santos-São Vicente Estuarine System tributaries according to the quality of sediment in the winter.

these levels are lower than those found in PC-RB sediments (with some compounds above the PEL). This difference probably was due to the dredging itself, which removes more contaminated material from the navigation channel.

\section{CONCLUSION}

The sediments of the Santos-São Vicente Estuarine System tributaries present a certain degree of degradation, especially those from the northern portion of the estuary (Quilombo River and the three sampling sites situated at Piaçaguera Canal). The evaluation of the metals concentrations revealed that all the sediments from the SSES are contaminated with $\mathrm{Hg}$ and $\mathrm{Pb}$, and some sites were somewhat contaminated with $\mathrm{As}, \mathrm{Cu}$, $\mathrm{Ni}$ and $\mathrm{Zn}$, which showed strong relationship with biological effects, together with PAHs. Sources of contamination seem to differ from site to site across the estuary, indicating local sources tend to be more important to the toxicities, with exception of the $\mathrm{Hg}$, which is spread in the system. This study also shows that degradation is not restricted to the main estuarine channels, evidencing both sediment contamination and toxicity in some tributaries of the SSES. Our results also show that the contamination management policies failed to avoid environmental degradation of the SSES and that more effective policies are necessary.

\section{ACKNOWLEDGEMENTS}

The authors would like to thank FAPESP (São Paulo State Research Foundation) for the Research Grant \# 03/12860-2 issued to A.A. Mozeto and the Grant \# 05/60598-0 to F.C. Perina. D. Abessa and A. Mozeto thank to CNPq (National Council for Scientific and Technological Development) for the research fellowships.

\section{REFERENCES}

ABESSA, D.M.S., SOUSA, E.C.P.M., RACHID, B.R.F. \& MASTROTI, R.R. 1998. Use of the burrowing Amphipod Tiburonella viscana as tool in Marine Sediments Contamination Assessment. Brazilian Arch. Biol. Technol., 41:225-230. http:// 
dx.doi.org/10.1590/S1516-89131998000200009

ABESSA, D.M.S., CARR, R.S., SOUSA, E.C.P.M., RACHID, B.R.F., ZARONI, L.P., GASPARRO, M.R., PINTO, Y.A., BÍCEGO, M.C., HORTELLANI, M.A., SARKIS, J.E.S. \& MUNIZ, P. 2008. Integrative Ecotoxicological Assessment of Contaminated Sediments in a Complex Tropical Estuarine System. In: Hofer, T.N. (ed) Marine Pollution: New Research. Nova Science Publishers, pp 279-312.

ABESSA, D.M.S., SOUSA, E.C.P.M., RACHID, B.R.F., ZARONI, L.P., GASPARRO, M.R., HORTELLANI, M.A. \& SARKIS, J.E.S. 2014a. Using Sets of Geochemical Analyses and Toxicity Tests to Assess the Effects of Sewage Disposal in Santos Bay, Brazil. J. Environ. Hum., 1(3): 34-47. http://dx.doi.org/10.15764/ EH.2014.03004

ABESSA, D.M. DE S., MORAIS, L.G., PERINA, F.C., DAVANSO, M.B., RODRIGUES, V.G.S., MARTINS, L.M. DE P. \& SÍGOLO, J.B. 2014b. Sediment Geochemistry and Climatic Influences in a River Influenced by Former Mining Activities: the Case of Ribeira de Iguape River, SP-PR, Brazil. Open J. Water Pollut. Treat., 1(1): 43-53. http://dx.doi.org/10.15764/ WPT.2014.01005

ANKLEY, G.T., KATKO, A. \& ARTHUR, J.W. 1990. Identification of ammonia as an important sediment-associated toxicant in the lower fox River and green bay, Wisconsin. Environ. Toxicol. Chem., 9(3): 313-322. http://dx.doi.org/10.1002/etc.5620090307

ANKLEY, G.T., SCHUBAUER-BERIGAN, M.K. \& HOKE, R.A. 1992. Use of toxicity identification evaluation techniques to identify dredged material disposal options: A proposed approach. Environ. Manage., 16(1): 1-6. http://dx.doi.org/10.1007/ BF02393904

ARAÚJO, G.S., MOREIRA, L.B., MORAIS, R.D., DAVANSO, M.B., GARCIA, T.F., CRUZ, A.C.F. \& ABESSA, D.M.S. 2013 Ecotoxicological assessment of sediments from an urban marine protected area (Xixová-Japuí State Park, SP, Brazil). Mar. Pollut. Bull., 75(1-2): 62-68. http://dx.doi.org/10.1016/j. marpolbul.2013.08.005

ARAÚJO, R.P.A., BOTTA-PASCHOAL, C.M.R., SILVÉRIO, P.F., ALMEIDA, F.V., RODRIGUES, P.F., UMBUZEIRO, G.A., JARDIM, W.F. \& MOZETO, A.A. 2006. Application of toxicity identification evaluation to sediment in a highly contaminated water reservoir in southeastern Brazil. Environ. Toxicol. Chem., 25(2):206-213. http://dx.doi.org/10.1897/05-144R.1

BAY, S.M., GREENSTEIN, D.J., LAU, S.-L., STENSTROM, M.K. \& KELLEY, C.G. 1996. Toxicity of dry weather flow from the Santa Monica Bay watershed. Bull. South. Calif. Acad. Sci., 95(1): 33-45. Available at: http://scholar.oxy.edu/scas/vol95/ iss $1 / 7$

BAYNE, B.L., BROWN, D.A., BURNS, K., DIXON, D.R., IVANOCI, A., LIVINGSTONE, D.R., LOWE, D.M., MOORE, M.N., STEBBING, A.R.D. \& WIDDINGS, J. 1985. The Effects of stress and pollution on marine animals. Praeger, New York. $384 p$.

BRASIL. 2012. Environmental National Council (CONAMA) Resolution no 454. Rev. Resol. no 344 de 2004 e no 421 de 2010. General Guidelines to the Evaluation of Dredged Material to be Disposed in Brazilian Jurisdictional Waters. Diário Of. da União 17

BURUAEM, L.M., CASTRO, Í.B., HORTELLANI, M.A., TANIGUCHI, S., FILLMANN, G., SASAKI, S.T., PETTI, M.A.V., SARKIS, J.E.S., BÍCEGO, M.C., MARANHO, L.A., DAVANSO, M.B., NONATO, E.F., CESAR, A., COSTALOTUFO, L.V. \& ABESSA, D.M.S. 2013. Integrated quality assessment of sediments from harbour areas in Santos-São Vicente Estuarine System, Southern Brazil. Estuar. Coast. Shelf.
Sci., 130: 179-189. http://dx.doi.org/10.1016/j.ecss.2013.06.006 CAMARGO, J.B.D.A., ARAÚJO, G.S., CRUZ. A.C.F., FONSECA, T.G. \& ABESSA, D.M.S. 2015. Use, development and improvement in the protocol of whole-sediment Toxicity Identification and Evaluation using benthic copepods. Mar. Pollut. Bull., 91(2): 511-517. http://dx.doi.org/10.1016/j. marpolbul.2014.10.015

CARR, R.S., MONTAGNA, P.A., BIEDENBACH, J.M., KALKE, R., KENNICUTT, M.C., HOOTEN, R. \& CRIPE, G. 2000. Impact of storm $\square$ water outfalls on sediment quallity in corpus Christi Bay, Texas, USA. Environ. Toxicol. Chem., 19(3): 561574. http://dx.doi.org/10.1897/1551-5028(2000)019<0561:IOS $\mathrm{WOO}>2.3 . \mathrm{CO} ; 2$

CCME. 2002. Canadian sediment quality guidelines for the protection of aquatic life: summary tables. Winnipeg, Canada: Canadian Council of Ministers of the Environment. Available at: http://st-ts.ccme.ca/en/index.html.

CESAR, A., PEREIRA, C.D.S., SANTOS, A.R., ABESSA, D.M.S., FERNÁNDEZ, N., CHOUERI, R.B. \& DELVALLS, T.A. 2006. Ecotoxicological assessment of sediments from the Santos and São Vicente Estuarine System - Brazil. Brazilian J. Oceanogr., 54(1): 55-63. http://dx.doi.org/10.1590/S167987592006000100005

CESAR, A.; ABESSA, D.M.S.; PEREIRA, C.D.S.; SANTOS, A.R.; FERNÁNDEZ, N.; CHOUERI, R.B. \& DELVALLS, T.A. 2009. A simple approach to integrate ecotoxicological and chemical data for the establishment of environmental risk levels. Brazilian Arch. Biol. Technol., 52(1): 233-240.

CHOUERI, R.B., CESAR, A., ABESSA, D.M.S., TORRES, R.J., MORAIS, R.D., RIBA, I., PEREIRA, C.D.S., NASCIMENTO, M.R.L., MOZETO, A.A. \& DELVALLS, T.A. 2009. Development of site-specific sediment quality guidelines for North and South Atlantic littoral zones: Comparison against national and international sediment quality benchmarks. J. Hazard. Mater., 170(1): 320-331. http://dx.doi.org/10.1016/j. jhazmat.2009.04.093

CUNHA, D.G.F., CALIJURI, M.D.C. \& MIWA, A.C.P. 2007. A precipitação pluviométrica como agente indutor de modificações nas características químicas do sedimento do rio Jacupiranguinha, Vale do Ribeira de Iguape, SP. Minerva, 4(1): 41-49. Available at: http://www.fipai.org.br/revista_minerva_eletro_v04n01.html

DU LAING, G., RINKLEBE, J., VANDDECASTEELEE, B., MEERS, E. \& TACK, F.M.G. 2009. Trace metal behaviour in estuarine and riverine floodplain soils and sediments: A review. Sci. Total Environ., 407:3972-3985. http://dx.doi.org/10.1016/j. scitotenv.2008.07.025

FORTUNATO, J.M., HYPOLITO, R., MOURA, C.L. \& NASCIMENTO, S.C. 2012. Caracterização da contaminação por metais pesados em área de manguezal, Município de Santos (SP). Rev. do Inst. Geológico, 33(1): 57-69. http://dx.doi. org/10.5935/0100-929X.20120004

HORTELLANI, M.A., SARKIS, J.E.S., BONETTI, J. \& BONETTI, C. 2005. Evaluation of mercury contamination in sediments from Santos - São Vicente Estuarine System, São Paulo State, Brazil. J. Braz. Chem. Soc., 16(6A): 1140-1149. http://dx.doi. org/10.1590/S0103-50532005000700009

HORTELLANI, M.A., SARKIS, J.E.S., ABESSA, D.M.S. \& SOUSA, E.C.P.M. 2008. Avaliação da Contaminação por Elementos Metálicos dos Sedimentos do Estuário Santos - São Vicente. Quim Nova, 31(1): 10-19. http://dx.doi.org/10.1590/ S0100-40422008000100003

HIROTA, J. \& SZYPER, J.P. 1976. Separation of total particulate carbon into inorganic and organic components. Limnol. Oceanogr., 20: 896-900. http://dx.doi.org/10.4319/ 10.1975.20.5.0896

JICKELLS, T.D. \& RAE, J.E. 1997. Biogeochemistry of Intertidal Sediments. Cambridge University Press, New York, USA. 205p. 
LAMPARELLI, M.C., COSTA, M.P., PRÓSPERI, V.A., BEVILACQUA, J.E., ARAÚJO, R.P., EYSINC, G.G.J. \& POMPÉIA, S. 2001. Sistema Estuarino de Santos e São Vicente "Levantamento da contaminação ambiental do sistema estuarino de Santos e São Vicente." PROCOP - Programa de Controle de Poluição, São Paulo, Brazil. 178p.

LONG, E.R., MACDONALD, D.D., SMITH, S.L. \& CALDER, F.D. 1995. Incidence of adverse biological effects within ranges of chemical concentrations in marine and estuarine sediments. Environ. Manage., 19(1): 81-97. http://dx.doi.org/10.1007/ BF02472006

LOTUFO, G.R. \& ABESSA, D.M.S. 2002. Testes de toxicidade com sedimentos total e água intersticial estuarinos utilizando copépodos bentônicos. In: Nascimento, I.A. \& Sousa, E.C.P.M. (eds) Métodos em Ecotoxicologia Marinha: Aplicações no Brasil. São Paulo, Brazil: Gráficas e Indústria Ltda, pp 151-162.

LUIZ-SILVA, W. \& MACHADO, W. 2012. Diluição geoquímica entre contaminantes sedimentares do estuário do rio Morrão, sistema estuarino de Santos-Cubatão, Brasil. Geochim. Bras., 26(1): 39-48.

LUIZ-SILVA, W., MATOS, R.H.R., KRISTOSCH, G.C. \& MACHADO, W. 2006. Variabilidade espacial e sazonal da concentração de elementos-traço em sedimentos do sistema estuarino de Santos-Cubatão (SP). Quim. Nova, 29(2): 256-263. http://dx.doi.org/10.1590/S0100-40422006000200016

MELO, S.L.R. \& ABESSA, D.M.S. 2002. Testes de Toxicidade com Sedimentos Marinhos utilizando Anfípodos. In: Nascimento, I.A. \& Sousa, E.C.P.M. (eds) Métodos em Ecotoxicologia Marinha: Aplicações no Brasil. São Paulo, Brazil: Gráficas e Indústria Ltda, pp 123-178

PEREIRA, M.O., CALZA, C., ANJOS, M.J., LOPES, R.T. \& ARAUJO, F.G. 2006. Metal concentrations in surface sediments of Paraiba do Sul River (Brazil). J. Radioanal. Nucl. Chem., 269(3): 707-709. http://dx.doi.org/10.1007/s10967-006-0290-7

PHILLIPS, B., ANDERSON, B. \& HUNT, J. 1997. Measurement and distribution of interstitial and overlying water ammonia and hydrogen sulfide in sediment toxicity tests. Mar. Environ. Res., 44(2): 117-126. http://dx.doi.org/10.1016/S01411136(96)00087-6

POWER, E.A. \& CHAPMAN, P.M. 1992. Assessing sediment quality. In: Burton A.G., J. (ed) Sediment toxicity assessment. Boca Raton, USA: Lewis Publisher, pp 1-18.

RAE, J.E. 1997. Trace metals in deposited intertidal sediments. In: Jickells, T.D. \& Rae, J.E. (eds) Biogeochemistry of intertidal sediments. New York, USA: Cambridge University Press, pp $16-41$.

SAGEMAN, B.B. \& LYONS, T.W. 2003. Geochemistry of finegrained sediments and sedimentary rocks. In: Davis, A.M., Holland, H.D., Turekian, K.K. (eds) Treatise on geochemistry. Sediments, diagenesis and sedimentary rocks. Amsterdam: Elsevier, pp 115-158.

CHEPIS, W.R., MEDEIROS, T.V., SILVA, S.A. \& ABESSA, D.M.S. 2016. Toxicidade aguda e contaminação por metais em sedimentos do Rio dos Bugres, Ilha de São Vicente, SP.
Brazilian J. Aquat. Sci. Technol., 20(1): 42-53. http://dx.doi. org/10.14210/bjast.v20n1.

TABACHNICK, B.G. \& FIDELL, L.S. 1996. Using Multivariate Statistics. Harper Collins College Publishers, New York. 996p.

TORRES, R.J., ABESSA, D.M.S., SANTOS, F.C., MARANHO, L.A., DAVANSO, M.B., NASCIMENTO, M.R.L. \& MOZETO, A.A. 2009. Effects of dredging operations on sediment quality: contaminant mobilization in dredged sediments from the Port of Santos, SP, Brazil. J. Soils Sediments 9:420-432. http://dx.doi. org/10.1007/s11368-009-0121-x

TORRES, R.J., CESAR, A., PASTOR, V.A., PEREIRA, C.D.S., CHOUERI, R.B., CORTEZ, F.S., MORAIS, R.D., ABESSA, D.M.S., DO NASCIMENTO, M.R.L., MORAIS, C.R., FADINI, P.S., DEL VALLS CASILLAS, T.A. \& MOZETO, A.A. 2015. A Critical Comparison of Different Approaches to SedimentQuality Assessments in the Santos Estuarine System in Brazil. Arch. Environ. Contam. Toxicol., 68(1): 132-147. http://dx.doi. org/10.1007/s00244-014-0099-2

USEPA (United States Environmental Protection Agency). 1991. Determination of Mercury in sediment by cold vapor atomic absorption spectrometry. Methods for the determination of metals in environmental samples. EPA 600/4-91/010, June 1991.

USEPA (United States Environmental Protection Agency). 1996a. Acid digestion of sediments, sludges and soils. Method 3050B. Revision 2, December 1996, 12 pp.

USEPA (United States Environmental Protection Agency). 1996b. Ultrasonic extraction. Method 3550B. Revision 2, December 1996, 12 pp.

USEPA (United States Environmental Protection Agency). 1996c. Silica Gel Clean-up. Method 3630c. Revision 3, December 1996, $12 \mathrm{pp}$.

USEPA (United States Environmental Protection Agency). 1996d. Semivolatile organic compounds by gas chromatography/mass spectrometry (GC/MS). Method 8270c. Revision 4, December 1996, 62 pp.

USEPA (United States Environmental Protection Agency). 1996e. Semivolatile organic compounds (PAHs and PCBs) in soils/sludges and solid wastes using thermal extraction/gas chromatography/mass spectrometry (TE/GC/MS). Method 8275a. Revision 1, December 1996, 23 pp.

USEPA (United States Environmental Protection Agency). 1998 Organochlorine pesticides by gas chromatography. Method 8081b. Revision 2, January 1998, 50 pp.

USEPA (United States Environmental Protection Agency). 2000. Polychlorinated biphenyls (PCBs) by gas chromatography. Method 8081b. Revision 1, November 2000, 56 pp.

WARD, D.J., PEREZ-LANDA, V., SPADARO, D.A., SIMPSON, S.L. \& JOLLEY, D.F. 2011. An assessment of three harpacticoid copepod species for use in ecotoxicological testing. Arch. Environ. Contam. Toxicol., 61(3): 414-425. http://dx.doi. org/10.1007/s00244-011-9646-2

WENTWORTH, C.K. 1992. A scale of grade and class terms for clastic sediments. J. Sediment. Petrol., 30: 377-390. 